nostra attenzione sui soggetti che presentavano livelli non evidenziabili di viremia plasmatica in almeno due prelievi sequenziali e su un gruppo di pazienti che avevano interrotto la terapia antiretrovirale per un periodo variabile da 11 a 24 mesi.

Risultati: I risultati ottenuti sui soggetti con carico virale costantemente non evidenziabile $(<50$ copie di HIV-1 $\mathrm{RNA} / \mathrm{ml}$ ) hanno messo in evidenza un carico di HIV-1 DNA significativamente più elevato nei soggetti "non responder" alla terapia e l'associazione tra un decremento significativo di HIV-1 DNA e un aumentato livello di cellule CD4+, nei soggetti che avevano risposto positivamente alla terapia retrovirale.

Conclusioni I dati ottenuti suggeriscono, pertanto, che la determinazione del DNA viral load potrebbe rappresentare un ulteriore marker per valutare l'efficacia della terapia antiretrovirale e al fine di disegnare e validare nuovi protocolli terapeutici.

\title{
LA DETERMINAZIONE QUANTITATIVA DI HIV-I DNA NEL FOLLOW-UP DEL PAZIENTE HIV-I INFETTO
}

Vitone F., Gibellini D., Schiavone P., Bon I., Re M.C.

Sezione di Microbiologia, Dipartimento di Clinica Specialistica e Sperimentale, Università di Bologna,

Introduzione: I continui progressi in campo biomolecolare hanno permesso lo sviluppo di tecniche sempre più raffinate e sensibili, applicabili sia nella diagnosi d'infezione da HIV1 sia nel monitoraggio del paziente infetto.

E' ormai noto come nel follow-up del soggetto HIV-infetto, una corretta valutazione dello stato del paziente si basa su parametri immunologici (CD4) e sul dosaggio della carica virale nel plasma, che risultano, quindi, essere i marker di elezione per impostare una corretta terapia e valutarne l'efficacia nel tempo.

Oggi però si ritiene che ulteriori parametri virologici possano fornire utili indicazioni e contribuire ad una migliore comprensione della dinamica dell'infezione e della patogenesi dell'AIDS. Tra questi la quantificazione del DNA provirale rappresenta di certo un riferimento fondamentale per valutare la consistenza del reservoir virale, che di fatto costituisce uno dei principali ostacoli all'eradicazione dell'infezione stessa.

Metodi: Per tale motivo abbiamo studiato la presenza di HIV-1 DNA nei linfomonociti ottenuti dal sangue periferico di 104 pazienti HIV-1 sieropositivi mediante un saggio di PCR quantitativa real-time focalizzando, in particolare, la 